\title{
The Impact of Motivation and Social Interaction on the E-Learning at Arab Open University, Kingdom of Bahrain
}

\author{
Sara Essam, Jaflah Al-Ammary \\ Department of Information Systems, College of IT, University of Bahrain, Sakhir, Kingdom of Bahrain \\ Email: sessam@uob.edu.bh, Jalammary@uob.edu.bh
}

Received June $29^{\text {th }}, 2013$; revised July $29^{\text {th }}, 2013$; accepted August $7^{\text {th }}, 2013$

\begin{abstract}
Copyright (C) 2013 Sara Essam, Jaflah Al-Ammary. This is an open access article distributed under the Creative Commons Attribution License, which permits unrestricted use, distribution, and reproduction in any medium, provided the original work is properly cited.
\end{abstract}

\begin{abstract}
E-learning can be considered as a useful tool for enhancing the quality of the educational process. However, the success of any technology application is dependent on how good it would satisfy the needs of its key stockholders, who compose the constituency of an organization and address their concerns. In the context of e-learning, students are the main stakeholders. Therefore, there is an emergent need to understand the factors that influence the use of e-learning to satisfy the students and improve their learning. The main aim of the current study is to investigate the factors that affect the use of e-learning by the postgraduate students at the Arab Open University. Factors such as motivation and social interaction were selected to be potential factors for using e-learning. Moreover, the effect of e-learning on the students' perceived satisfaction and performance was examined. The study sample is comprised of postgraduate students enrolled in the AOU - the Kingdom of Bahrain branch. One hundred and fifty surveys were distributed both in person and as a web survey. The results provide a great indication about the use of e-learning at the Kingdom of Bahrain. Results on the research model and hypotheses show that motivation is the main factor that has the most significant impact on using e-learning at the AOU, followed by student-student interaction. Student-instructor interaction has shown to have an indirect impact on e-learning via motivation.
\end{abstract}

Keywords: Arab Open University; E-Learning; Motivation; Student-Student Interaction; Student-Instructor Interaction; Student's Perceived Satisfaction; Students' Performance

\section{Introduction}

E-learning presents new channels and approaches for the traditional method of teaching and learning. It is one of the innovative approaches for learning which challenge the traditional style of teaching and change the lecturers' work patterns (Freire, 1994; Singh et al., 2005). E-learning is defined as the use of modern ICT and emergent media such as Internet, satellite broadcast, interactive TV and so on to deliver instruction, information and learning content (Freire, 1994; Selim, 2007). Elearning provides more emergent teaching tools that facilitate more effective teaching methods compared to that of the traditional teaching methods (Volery et al., 2002). With e-learning, instructors' schedules are redefined, as well as their duties and relationships toward students (Young, 2002). Instructors are provided with superior teaching tools and methods, allowing them to test students in real business situations (Singh et al., 2005). In addition they are given the opportunity to distribute up-to-date course content in relatively no time and apply knowledge in contemporary situations (Teare, 2000). Moreover, using such innovative learning tools, instructor can eliminate the students' technical frustrations, enhance their social interaction and encourage their involvement in an online community (Singh et al., 2005).

Although e-learning may increase access flexibility, eliminate geographical barriers and improve convenience and effec- tiveness of learning, there are still many questions raised by the researchers about the effectiveness of e-learning and to what extent it can be a satisfactory method for teaching. Singh (2005) stated that e-learning should not be considered as an alternative to the traditional teaching method. E-learning suffers from many factors that may affect its preference compared to the traditional face-to-face methods. Among these factors are, the feeling of isolation caused by the lack of social interaction between learners and instructors and between learners and other learners, the students' motivation to use e-learning, their comfort with the new technology in which the technical and academic support is ambiguous, and the students' low self-confidence in their abilities to use the technology. Rovai (2002) indicated that there is higher incidence of withdrawal or incomplete grades among students using e-learning. Many students had some negative feelings and beliefs toward online learning. They believe that technology will degrade higher education and will ruin the special relationships between instructors and students, and between students and other students that create a productive learning community (Rovai et al., 2003). Students also believe that the traditional course delivery and the classroom create an environment that is more responsive to their learning needs which would result in increasing the effectiveness of their learning (Wagner et al., 2008). Moreover, many students feel uncomfortable using online settings, as they are often required to find the answers themselves using available 
resources.

The Arab Open University (AOU) is a non-profit institution aiming at offering a large and diverse population of students, an efficient access to higher education and lifelong learning, despite the place and time boundaries and social economic backgrounds. The AOU is following a high quality teaching and learning process, and employing effective media and technologies for education and assessment; in order to provide the most academic support to the students, and to extend and enhance lifelong learning. To ensure a superior learning and knowledge building experience for students, AOU is applying blended learning, which is one of the e-learning categories (Singh, 2003). Thus, AOU allows students to obtain a complete integrated blend of learning resources, in which they have the ability to obtain the learning material package as well as online access to a virtual learning environment that offers most of the features that are available in the real classroom.

As any educational institute running in an Arabic country, AOU is still unable to satisfy their students specially the postgraduate. Many students at the AOU withdraw after one year or less. E-learning technology can be considered as useful tool for enhancing the quality of teaching and learning process. However, the success of any technology application is dependent on the extent to which it satisfies the needs and addresses the concerns of its key stakeholders, who compose the constituency of an organization (Thompson et al., 2001). In the context of elearning, students are the main stakeholders. Therefore, there is an emergent need to understand the factors that influence the use of e-learning to satisfy the students and improve their learning. The current study aims at investigating factors that affect the use of e-learning by the postgraduate students at the Arab Open University. Factors such as motivation and social interaction were selected to be potential factors for use of e-learning. Moreover, the effect of e-learning on the students' perceived satisfaction and performance will be examined.

\section{Factors Affecting the Use of E-Learning}

The e-learning is not always a successful project (Miller, 2010) and off course not all of them are a failure projects. Hence, to achieve a high success level in adopting e-learning as a new learning approach, factors impacting the e-learning should be identified and maintained. One of the factors that need to be maintained is the students' demography. The age, gender, marital and working statuses have been found to have a significant influence on predicting the students' interest in online education (Alstete et al., 2004; Hong, 2002). Gender, for instance, has been found in previous studies to be a very influential factor in terms of using e-learning (Coldwell et al., 2008). Thus, online courses tend to favor women, as they are generally more motivated, more network oriented, more collaborative, and better at scheduling their time (Coldwell et al., 2008). Moreover, Alstete and Beutell (2004) stated that when it comes to the use of e-learning, the age has been found to be a significant factor. Older students are more likely to engage in elearning than younger students in terms of using discussion boards and other related tools (Coldwell et al., 2008). Younger students are less self-directed and self-disciplined. A third demographic factor that has been found to affect the use of e-learning is the working status. Cain (2008) indicated that college student employment has been increasing steadily for at least four decades and many full time and part time employees are moving to online learning due to its convenience and flexibility with their work schedule.

Different people would have different approaches to learning. These individual differences are called by psychologists, learning styles (Stash et al., 2010). Learning styles affect the ways that people attach their own meanings to the topic being taught and help them develop schemas for learning (Roi, 2006). It has been found by Price (2004) that learning styles are particularly important in the context of web-based learning. Moreover, Roi (2006) found that students learning styles had affected their grade performance in online learning. Lecturers' attitudes toward the e-learning systems have been found to be affecting the students' attitudes and performance. Hammoud, Love and Brinkman (2008) revealed that instructors of electronic courses are playing a key role in encouraging students to use e-learning systems such as WebCT and use its tools to communicate. The study also found that the instructors' feedback and their observation of the students' progress affect the students' attitude towards e-learning positively. Moreover, researchers have found that high computer self-efficacy level could be an important factor in helping people build technical skills and use computers (Busch, 1995). Other factors that may impact using elearning include: how comfort is the learner with the technology, the presence of technical support, the ability to communicate and work with peer learners, the complex relationship between cognitive factors and the special nature of human-machine interfaces in learning process (Miller, 2005). In general, the above mentioned factors can be categorized in different ways. Sun, Tasi, Finger, Chen and Yen (2008) for instance, have identified six dimensions for the factors that impacting the use of e-learning which include: the learner, instructor, course, technology, design and environmental factors. Selim (2007) however, identified four categories including the student, information technology, instructor and the university support.

\section{Research Model and Hypotheses}

The current research study has a main objective of investigating factors that affect the use of e-learning by the postgraduate students at the AOU. Moreover, the effect of e-learning on the students' perceived satisfaction and performance will be examined. The literature revealed for many factors that may affect the use of e-learning. For the purpose of the current research, factors such as motivation and social interaction were selected.

The research model is developed as depicted in Figure 1. The research model depicted in the figure illustrates that motivation has a direct effect on using e-learning. However, both student-instructor and student-student interaction have a direct and indirect impact via motivation on the use of e-learning. E-learning, on the other hand, has an effect on both students' perceived satisfaction and students' performance.

\section{Research Model and Hypotheses}

\section{Interaction Direct and Indirect Impact on Using E-Learning}

Interaction can be defined as the interrelationship and exchange between individuals and groups in which they are influencing each other (Wagner, 1994). Interaction focuses on the interpersonal behaviors in a learning community (Rovai et al., 2003). It is the fundamental of the academic teaching as stu- 
dents can actively involved in an intentional process in order to learn (Colaric et al., 2001; Moore et al., 1990; Cao et al., 2008). The interaction is essential for students to formulate their questions, evaluate the responses/answers which will enhance their understanding (Cao et al., 2008). Three types of interaction have been identified to be considered in distance education and online learning (Moore, 1989; Sher, 2009): student-content, student-student and student-instructor interaction. In the elearning environment the course materials which can include text, audio, videotape, CD-ROM, or computer program are provided online through what actual learning process can be done. Therefore, student-content interaction is essential as it is the way by which students access and interact with the course materials in order to internalize information they come across (Sher, 2009; Murray et al., 2012). Student-instructor interaction can be done on different forms such as delivering and presenting information, providing feedback, and encouraging and guiding students (Sher, 2009; Paechter et al., 2010). Students can also interact with their instructors by asking questions and communicating with them regarding course activities (Sher, 2009; Murray et al., 2012). Student-student interaction on the other hand, is a way in which students are involved in collaborative activities in the present or absence of the instructors (Sher, 2009). They aim at exchanging information and ideas about the course to accomplish different types of course assessments (assignment/project) as well as sharing knowledge (Sher, 2009; Murray et al., 2012). For the purpose of the current research, only the social interaction, which includes studentinstructor and student-student, will be investigated.

Interaction has been found to be a critical element for the overall success and effectiveness of distance education and e-learning (Rovai, 2002; Sher, 2009; Neo, 2003). Without interpersonal interaction students will not be able to grasp, acquire, and develop knowledge. E-learning environment is limited by the difficult interaction (Sher, 2009). The transactional distance in such environment makes it difficult for the instructors and students to interact in the same physical and sequential space (Moore, 1989). Many researchers support the idea that the student-instructor and student-student interactions are important elements in the design and successful implementation of online learning courses (Coldwell et al., 2008). Rovai (2002) indicated that students may favor online learning because they experience a sense of online community, enjoy mutual interdependence and sense of trust and interaction among community members. Moreover, Neo (2003) stated that there are many advantages students gain through their use of e-learning, such as teamwork and critical thinking. Peer interaction is an impor-

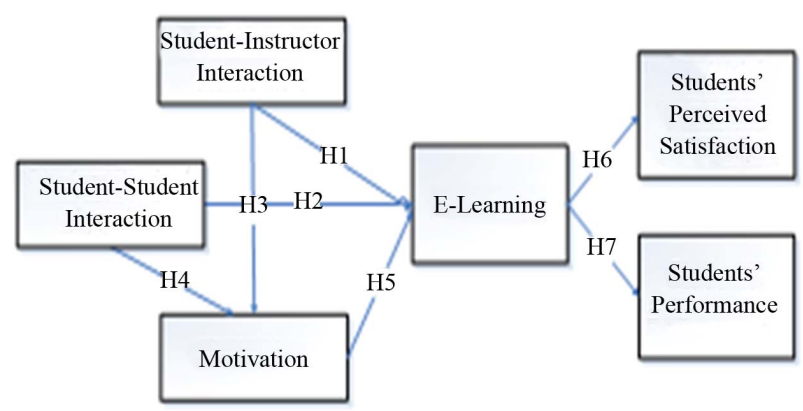

Figure 1.

Research model. tant determinant for an effective learning as student can build many imperative skills via the collaborative e-learning, such as teamwork, collaboration and critical thinking (Neo et al., 2009). Moreover, continuous and recursive interaction between students and instructors is essential for building knowledge and sustaining an effective learning process (Bruner, 1960; Bruner, 1996; Pask, 1975). In fact, many studies conducted on distance education, revealed that interaction is the key to effective distance education (Bernard et al., 2004; Lou et al., 2006; Zhao et al., 2005). Therefore, the following hypotheses have been developed:

\section{H1: Student-instructor interaction has a positive effect on using e-learning at AOU.}

\section{$\mathrm{H} 2$ : Student-student interaction has a positive effect on using e-learning at AOU.}

The interaction (student-student or student-instructor) can be considered as "the heart of the learning experience" in both the traditional and online learning environment (Wanstreet, 2006). It is the key to motivating students to learn, maintain and enhance their interest in the subject, as well as providing emotional support, which are all critical for building knowledge and enhancing the student performance (Cao et al., 2008; Moore, 1989; Sher, 2009; Paechter et al., 2010). The instructor presence and interaction with students has shown to be positively related to student learning and motivation (Baker, 2010). When students have a strong relationship with their instructors they will believe more in their instructors and more motivated to be involved in the learning process (Llias et al., 2012). On the other hand, there are few researches that revealed on the significant effect of the student-student interaction on motivation. However, with this type of interaction, students benefit in many ways such as working in small groups to construct understanding, socio-emotional support, and learning within an intercomnected environment (Paechter et al., 2010) which may motivate the students to do better in the e-learning environment. Therefore, the following hypotheses have been developed:

H3: Student-instructor interaction has a positive effect on the student motivation to use e-learning at AOU.

H4: Student-student interaction has a positive effect on the student motivation to use e-learning at AOU.

\section{Motivation Direct Impact on Using E-Learning}

Motivation is defined by Certo et al. (2006) as "the inner state that causes an individual to behave in a way that ensures the accomplishment of some goals". Motivation to perform a behavior can be divided into two main types: intrinsic and extrinsic motivation (Cain, 2008; Young, 2005; Hennessey et al., 2005). Extrinsic motivation is the drive of behaviors to achieve valued outcomes that are distinct from the activity itself such as external rewards, benefits, punishments, or obligations (Hennessey et al., 2005; Deci et al., 1985). Intrinsic motivation is the satisfaction gained from performing the behavior (Hennessey et al., 2005). Literature in educational psychology asserts that student motivation is a significant factor in e-learning (Cain, 2008). Both intrinsic and extrinsic motivations can be conceptualized and measured as influential indicators for students' satisfaction, enjoyment and excitement (Young, 2005). Students are having different wants, needs, and beliefs regarding the amount of 
effort they spend in completing a degree program. For instance, students may select the e-learning because they need to be at home during a particular class time or they may be unable to attend college except by an online learning method. With this flexible format of learning, self-motivation seems to be mandatory (Cain, 2008). Cain (2008) found that the main cause of the incompletion of an e-learning program is poor student motivation. A high motivation level is necessary for students to be successful in e-learning (Cain, 2008; Ergul, 2004). In other words, students who are motivated will perceive greater success and satisfaction than those who are not (Zurita et al., 2007). Therefore, the following hypothesis has been developed:

H5: Motivation has a positive effect using e-learning at AOU.

\section{Students' Perceived Satisfaction}

Satisfaction is widely accepted as a desirable outcome of any product or service experience (Siritongthaworn et al., 2006). In e-learning, satisfaction is an important indicator of success. Many studies indicated that user satisfaction is the key predecessor to predict success of a particular technology (Delone et al., 2003), or to predict a users' behavior of using such technology (Bhattacherjee, 2001). When students use e-learning, they tend to experience a new learning environment through many activities, such as the engagement in discussion board postings or online group assignments or exercises (Glass et al., 2008), which enhances their proactive thinking and learning. This engagement can increase the students' satisfaction with using e-learning (Glass et al., 2008). Therefore, the following hypothesis has been developed:

H6: The e-learning has a positive effect on the students' perceived satisfaction at AOU.

\section{Students' Performance}

Students' performance can be measured with the presence of a number of indicators including successful completion of or withdrawing a course, improved grades and building knowledge and skills (Coldwell et al., 2008). For the purpose of this study, performance is defined by the level of learning, level of understanding, built skills, and expected grades. It has been shown in previous studies that students enrolled on e-learning courses perform better than those enrolled in traditional schemes (Singh et al., 2005; Coldwell et al., 2008). Intel Corporation (2009) conducted a study on the positive impact of e-learning, and more than 80 percent of teachers surveyed said that students were more engaged and more actively involved in their learning and produced higher quality work. This supports the results of the study by Alstete and Beutell (2004), which indicated that the active participation and involvement of students using e-learning is positively and significantly related to overall course performance for MBA students.

Therefore, the following hypothesis has been developed:

H7: The e-learning has a positive effect on the students' performance at AOU.

\section{Research Methodology}

The study sample is comprised of postgraduate students enrolled in the AOU the Kingdom of Bahrain branch. The AOU offers two Master programs one in the Information Systems and the other in the Business administration. Two hundred surveys were distributed both in person and as a web survey. Only one hundred and fifty completed questionnaires were returned, 70 of them were completed using the web survey. The survey instrument provides a response rate of $75 \%$ which is considered as very high rate bearing in mind the difficulty in getting the permission to conduct the survey in the university. In addition, many students refused to answer the questionnaire either because they were very busy or they were not interested.

The survey instruments for this study was developed using validated items from the prior researches. As such, scales for measuring motivation, student-students interaction and student-instructor interaction were developed by adopting items from the measurements of (Cain, 2008; Sher, 2009; O'malley et al., 1999). The measurement for students' performance and students' perceived satisfaction was developed by adopting items from (O'Malley et al., 1999; Lee et al., 2009; Lee et al., 2008). Scales of using e-learning was developed by the authors for the purpose of the current research. Most of the items were measured on a five-point Likert-scale anchored at both extremes to 1 (strongly disagree) and 5 (strongly agree). The midpoint (3) represents the state of unsure or "neutral".

\section{Data Collection and Research Variables}

\section{Demographics}

Demographic characteristics of the overall participants are presented in Tables 1-5. Most of the postgraduate students that participated in the current research are male $(63.30 \%)$, are from Kingdom of Saudi Arabia (51.3\%) or Kingdom of Bahrain $(35.3 \%)$ and are mature (age between 25 and 40$)(84 \%)$ as shown in Tables 1 and 2. Moreover, most of the participants are married (71\%) and are working (89\%) (Tables 3 and 4). The majority of the worked participants are married $(66 \%)$ and from Kingdom of Saudi Arabia (57\%) as shown in Table 3 and Table 4. On the other hand, the results show that most of the participants are studying business administration $(80 \%)$ as shown in Table 5.

Table 1.

Selected characteristic of the sample (nationality and gender).

\begin{tabular}{cccccc}
\hline \multirow{2}{*}{ Gender } & \multicolumn{4}{c}{ Nationality } & \multirow{2}{*}{ Total } \\
\cline { 2 - 5 } & Bahraini & Saudi & Kuwaiti & Other & \\
\hline Male & $12.70 \%$ & $42.70 \%$ & $0.70 \%$ & $7.30 \%$ & $63.30 \%$ \\
Female & $22.70 \%$ & $8.70 \%$ & $0.00 \%$ & $5.30 \%$ & $36.70 \%$ \\
Total & $35.30 \%$ & $51.30 \%$ & $0.70 \%$ & $12.70 \%$ & $100 \%$ \\
\hline
\end{tabular}

Table 2.

Selected characteristic of the sample (age).

\begin{tabular}{cc}
\hline Age & $\%$ \\
\hline Less than 25 & $7.50 \%$ \\
Between 25 and 30 & $42.70 \%$ \\
Between 30 and 35 & $25.30 \%$ \\
Between 35 and 40 & $16.00 \%$ \\
More than 40 & $8.70 \%$ \\
Total & $100 \%$ \\
\hline
\end{tabular}


Table 3.

Selected characteristic of the sample (working status and country of residence).

\begin{tabular}{|c|c|c|c|c|c|c|}
\hline \multicolumn{6}{|c|}{ Having a job (are you working?) } & \multirow{3}{*}{$\begin{array}{c}\text { Total } \\
(\%)\end{array}$} \\
\hline \multirow{4}{*}{$\begin{array}{l}\text { Having a job } \\
\text { (working?) }\end{array}$} & & \multicolumn{4}{|c|}{ Country of residence $(\%)$} & \\
\hline & & Bahrain & Saudi Arabia & Kuwait & Other & \\
\hline & Yes & 37.30 & 51.30 & 0.70 & 0 & 89.3 \\
\hline & No & 4.00 & 6.0 & 0.0 & 0.70 & 10.7 \\
\hline Total & & 41.30 & 57.3 & 0.7 & 0.70 & 100.0 \\
\hline
\end{tabular}

Table 4.

Selected characteristic of the sample (marital and working status).

\begin{tabular}{ccccc}
\hline & \multicolumn{3}{c}{ Having a job (are you working?) } & \multirow{2}{*}{ Total } \\
\cline { 2 - 3 } Marital & \multicolumn{2}{c}{ Yes } & No & \\
Status & Single & $23.30 \%$ & $5.30 \%$ & $28.70 \%$ \\
& Married & $66.00 \%$ & $5.30 \%$ & $71.30 \%$ \\
\multicolumn{2}{c}{ Total } & $89.30 \%$ & $10.70 \%$ & $100.00 \%$ \\
\hline
\end{tabular}

Table 5.

Selected characteristic of the sample (field of study).

\begin{tabular}{cc}
\hline Field of study & $\%$ \\
\hline Information technology & $20.00 \%$ \\
Business administration & $80.00 \%$ \\
\hline
\end{tabular}

\section{Model Measurements Assessment}

The strength of the measurement model is determined by its reliability and validity. Cronbach' alpha was used to assess the reliability value of each dimension as demonstrated in Table 6. All the reliability values are higher than 0.7 .

Moreover, to assess the convergent validity confirmatory factor analysis with Varimax rotation was conducted to assess the underlying structure for the items of each research construct. The loading of each factor should be greater than or equal to 0.5 which has been achieved. Results are shown in Tables 7 and 8.

\section{Hypotheses Testing}

To test the research model regression analyses were conducted. The first regression analysis was performed to test the relationships between student-student interaction, student-instructor interaction and motivation in a way to examine the indirect impact of social interaction on the e-learning as shown in Table 9.

The results show that student-student interaction $(\beta=0.187, \mathrm{t}$ $=2.166)$, and student-instructor interaction $(\beta=0.376, \mathrm{t}=$ 4.353 ) have a positive effect on motivation. The results indicate that student-instructor interaction has more impact on the motivation than that of student-student interaction. Thus the $26 \%$ of the variance on the motivation is caused mostly by students-instructor interaction as shown in Table $\mathbf{1 0 .}$

The second regression analysis was conducted to test the direct impact of the student-student interaction and student-in- structor interaction on the using e-learning. In addition it will examine the relationship between motivation and using e-learning as shown in Table 9. The results demonstrated that both student-student interaction and motivation have a significant effect on using e-learning $(\beta=0.140, t=2.837)$ and $(\beta=0.815$, $\mathrm{t}=17.578)$ respectively. The results however, indicate that student-instructor interaction has no direct effect on using elearning $(\beta=-0.009, \mathrm{t}=-0.170)$. The results whereas moreover, reveal that $77 \%$ of the variance in using e-learning is caused mostly by motivation.

The other regression analyses were conducted to test the impact of using e-learning on both students' perceived satisfaction and students' performance. The results are shown Table 9. The results demonstrated that the e-learning has a significant impact on both students' perceived satisfaction $(\beta=0.486, t=6.768)$ and students' performance $(\beta=0.383, \mathrm{t}=5.039)$. The model

Table 6.

Results for reliability analysis.

\begin{tabular}{cc}
\hline Construct & Cronbach's alpha \\
\hline E-learning & 0.854 \\
Student-instructor interaction & 0.759 \\
Student-student interaction & 0.786 \\
Motivation & 0.833 \\
Perceived satisfaction & 0.892 \\
Performance & 0.906 \\
\hline
\end{tabular}

Table 7.

Results for factor analysis.

\begin{tabular}{ccc}
\hline Factor & Items & Loading of each factor \\
\hline \multirow{3}{*}{ Motivation } & M_1 & 0.649 \\
& M_3 & 0.829 \\
& M_4 & 0.831 \\
Perceived & M_5 & 0.783 \\
Satisfaction & M_6 & 0.797 \\
& S_1 & 0.701 \\
& S_2 & 0.675 \\
& S_3 & 0.690 \\
& S_5 & 0.851 \\
& S_6 & 0.892 \\
& S_7 & 0.824 \\
& P_1 & 0.851 \\
& P_2 & 0.815 \\
& P_3 & 0.873 \\
& P_4 & 0.776 \\
& P_5 & 0.884 \\
& P_6 & 0.840 \\
& & 0.770 \\
\hline
\end{tabular}


Table 8.

Results for factor analysis (continue).

\begin{tabular}{clc}
\hline Factor & Items & Loading of each factor \\
\hline \multirow{5}{*}{ E-learning } & EL_1 & 0.828 \\
& EL_2 & 0.625 \\
& EL_3 & 0.761 \\
& EL_4 & 0.807 \\
& EL_5 & 0.746 \\
Student-instructor & EL_6 & 0.811 \\
interaction & SII_1 & 0.681 \\
& SII_5 & 0.765 \\
& SII_6 & 0.810 \\
Student-student interaction & SI_8 & 0.789 \\
& SS_2 & 0.788 \\
& SS_3 & 0.818 \\
& SS_4 & 0.907 \\
\hline
\end{tabular}

Table 9.

Model testing results.

\begin{tabular}{|c|c|c|c|c|}
\hline & Hypothesis & $\boldsymbol{\beta}$ & $\mathbf{t}$ & Status \\
\hline H1 & $\begin{array}{c}\text { Student-instructor interaction } \rightarrow \\
\text { use of e-learning }\end{array}$ & 0.009 & -0.170 & Rejected \\
\hline $\mathrm{H} 2$ & $\begin{array}{c}\text { Student-student interaction } \rightarrow \\
\text { use of e-learning }\end{array}$ & 0.140 & 2.837 & Accepted \\
\hline $\mathrm{H} 3$ & $\begin{array}{c}\text { Student-instructor interaction } \rightarrow \\
\text { motivation }\end{array}$ & 0.376 & 4.353 & Accepted \\
\hline $\mathrm{H} 4$ & $\begin{array}{c}\text { Student-student interaction } \rightarrow \\
\text { motivation }\end{array}$ & 0.187 & 2.165 & Accepted \\
\hline H5 & Motivation $\rightarrow$ e-learning & 0.815 & 17.578 & Accepted \\
\hline H6 & $\begin{array}{l}\text { Use of e-learning } \rightarrow \text { students' } \\
\text { perceived satisfaction }\end{array}$ & 0.486 & 6.768 & Accepted \\
\hline $\mathrm{H} 7$ & $\begin{array}{c}\text { Use of e-Learning } \rightarrow \text { students' } \\
\text { performance }\end{array}$ & 0.383 & 5.039 & Accepted \\
\hline
\end{tabular}

Table 10.

Explanation of variance.

\begin{tabular}{cc}
\hline Factor & $\mathbf{R}^{\mathbf{2}}$ \\
\hline Motivation & 0.247 \\
Use of e-learning & 0.672 \\
Students' perceived satisfaction & 0.231 \\
Students' performance & 0.141 \\
\hline
\end{tabular}

moreover, explained low variance of students' perceived satisfaction and students' performance. Thus, e-learning caused only $23 \%$ of the variance in students' perceived satisfaction and $14 \%$ of the variance in the students' performance as demonstrated in Table 10.

\section{Discussion and Conclusion}

The current research was conducted to achieve two main ob- jectives. The first objective was to investigate the factors affecting the use of e-learning by the postgraduate students at the AOU. The second main objective was to examine the impact of using e-learning on the students' perceived satisfaction and performance. The research findings revealed that most of the hypotheses investigated were strongly supported, except for that related to the direct effect of student-instructor interaction on using e-learning.

The findings of the current research provide a great indication about the using of e-learning at the AOU. The results revealed that $37 \%$ of the participants were females. The results indicate that the percentage of women using e-learning is acceptable peering in mind their duties as wives and mothers in addition to their employment commitments. The results confirm that the e-learning is attracting women especially in the context of the Arab countries. Women in such countries try to involve in a virtual learning environment whenever they find it difficult to enroll in a traditional and physical learning environment. Moreover, the results revealed that around $84 \%$ of the total respondents were in the age range of 25 and 40 years, in which the students are more mature and self-directed. Older students are more likely to engage in e-learning than younger students because younger students are still dependent and need to be directed and advised by the others such as their instructors (Coldwell et al., 2008). In addition, the results show that around $71 \%$ of the respondents are married, and almost $90 \%$ of them are working. This is supporting the opinion of Mrs. Dana Lori's - an examination administrator at AOU—on the enrolled students at AOU. Mrs. Dana demonstrates that most of the postgraduate students favor the e-learning method provided by AOU because they are married and working. They find this learning system a good opportunity to save their time, providing them with the required learning resources, and allowing them to attend online sessions. Thus, they can have an enough space to finish their desired degree while taking care of their homes, children, and work duties. In addition, Mrs. Dana states that students are favoring the e-learning method provided by AOU because most of them are Saudis and are not living in Bahrain which has been supported by the findings of the current research. The results indicate that almost half of the respondents $(51.0 \%)$ are Saudis, and $57.3 \%$ are not living in Bahrain. Finally, the results revealed that almost $80 \%$ of the respondents were registered in the Business Administration, and that $44 \%$ of them were in the second year of their study. Information systems sometimes are found to be a more complicate and difficult subject to be studied in a distance learning system without the support of the physical learning environment.

Results on the research model and hypotheses show that the motivation is the main factor that has the most significant impact on using e-learning at the AOU, followed by student-student interaction. Motivation is predicted to be an effectual factor for using e-learning (Cain, 2008; Ergul, 2004; Smith, 2010). A high level of motivation is necessary for students to be successful in e-learning environment (Ergul, 2004). Motivation is "the internal force that drives an individual to move toward the goal after perceiving a plan" (Lee et al., 2010). If the students are motivated they will be encouraged to be effectively involved in the learning process and gain the expected success.

Regarding the direct and indirect impact of the social interaction on using e-learning, the results demonstrate that studentstudent interaction shows significant direct and indirect impact via the motivation on using e-learning. The results moreover, 
indicate that student-instructor interaction has no direct effect on using e-learning. However, via its impact on the motivation, student-instructor interaction can indirectly impact the using of e-learning. These findings confirm the importance of the faceto-face interaction and the social communication for students' involvement in a learning process as a part of the Arab culture.

The findings finally demonstrate that using e-learning by students at AOU has a positive and significant effect on both students' perceived satisfaction and students' performance. Elearning was found to have a positive impact on students' performance as it can increase the student engagement and motivation (Coldwell et al., 2008). Moreover, when students engage in an e-learning program, they are looking for building learning experiences and knowledge (Siritongthaworn et al., 2006) through accessing online resources and gaining new technical skills (Cain, 2008), which increase their satisfaction (Glass et al., 2008).

E-learning has become an integral part of higher education in which universities can no longer ignore this new learning environment. Therefore, in order to improve persistence in e-learning programs, as well as increase the e-learners satisfaction and performance, educational institutes need to address the factors that may impact the using of e-learning. Educational institutions thus, need to support and motivate students when making the adjustment to learning through such different learning environment. Students' motivation needs to be enhanced by encouraging the social interaction both between student-student and student-instructor interaction and facilitating the learning within social and community based environment. Moreover, a learning strategy needs to be developed with a goal of increasing students' retention by providing an effective academic and technical support and promoting a sense of social community. Teachers' presence needs also to be enhanced. The positive behaviors are important in delivering successful e-learning, increased student satisfaction and improved performance.

\section{REFERENCES}

Alstete, J., \& Beutell, N. (2004). Performance indicators in online distance learning courses: A study of management education. Journal of Quality Assurance in Education, 12, 6-14. http://dx.doi.org/10.1108/09684880410517397

Baker, G. (2010). The impact of instructor immediacy and presence for online student affective learning, cognition, and motivation. The Journal of Educators Online, 7.

Bernard, R., Abrami, P., Lou, Y., Borokhovski, E., Wade, A., Wozney, L., Wallet, P., Fiset, M., \& Huang, B. (2004). How does distance education compare to classroom instruction? A meta-analysis of the empirical literature. Review of Educational Research, 74, 379-439. http://dx.doi.org/10.3102/00346543074003379

Bhattacherjee, A. (2001). Understanding information systems continuance: An expectation-confirmation model. MIS Quarterly, 25, 351370. http://dx.doi.org/10.2307/3250921

Bruner, J. (1960). The process of education. Cambridge, MA: Harvard University Press.

Bruner, J. (1966). Toward a theory of instruction. Cambridge, MA: Harvard University Press.

Busch, T. (1995). Gender differences in self-efficacy and attitudes toward computers. Journal of Educational Computing Research, 12, 147-158. http://dx.doi.org/10.2190/H7E1-XMM7-GU9B-3HWR

Cain, J. (2008). An analysis of motivation orientations and social interactions on successful and poor learners in an e-learning environment. Doctoral Dissertation, Tui University, College of Education, Available Online at ProQuest.

Cao, J., Crews, J., Lin, M., Burgoon, J., \& Nunamakr, J. (2008). An empirical investigation of virtual interaction in supporting learning. The DATA BASE for Advances in Information Systems, 39, 51-68. http://dx.doi.org/10.1145/1390673.1390680

Certo, S., \& Certo, S. (2006). Modern management (10th ed.). New Jersy: Pearson Prentice Hall.

Colaric, S., \& Jonassen, D. (2001). Information equals knowledge, searching equals learning, and hyperlinking is good instruction: Myths about learning from the World Wide Web. In C. D. Maddux, $\&$ D. L. Johnson (Eds.), The web in higher education: Assessing the impact and fulfilling the potential (pp. 159-169). New York: Haworth.

Coldwell, J., Craig, A., Paterson, T., \& Mustard, J. (2008). Online students: Relationships between participation, demographics and academic performance. The Electronic Journal of e-Learning, 6, 19-30.

Deci, E., \& Ryan, R. (1985). Intrinsic motivation and self-determination in human behavior. New York: Plenum. http://dx.doi.org/10.1007/978-1-4899-2271-7

DeLone, W., \& McLean, E. (2003). The DeLone and McLean model of information systems success: A ten year update. Journal of Management Information Systems, 19, 9-30.

Ergul, H. (2004). Relationship between student characteristics and academic achievement in distance education and application on students of Anadolu University. Turkish Online Journal of Distance Education, 5, 81-90.

Freire, P. (1994). Pedagogy of the oppressed (3rd ed.). New York: Continuum Publishing Company.

Glass, J., \& Sue, V. (2008). Student preference, satisfaction, and perceived learning. MERLOT Journal of Online Learning and Teaching, 4, 325-338.

Hammoud, L., Love, S., \& Brinkman, W. (2008). The affect of lecturers' attitude on students' use of an online learning environment. Proceeding of the 15th European Conference on Cognitive Ergonomics: The Ergonomics of Cool Interaction, Portugal.

Hennessey, B., \& Amabile, T. (2005). Extrinsic and intrinsic motivation. Blackwell, Encyclopedic Dictionary of Organizational Behavior, $1-1$.

Hong, K. (2002). Relationships between students' and instructional variables with satisfaction and learning from a Web-based course. Internet and Higher Education, 5, 267-281. http://dx.doi.org/10.1016/S1096-7516(02)00105-7

Ilias, K., \& Nor, M. (2012). Influence of teacher-student interaction in the classroom behavior on academic and student motivation in teachers' training institute in Malaysia. Academic Research International, 2.

Intel Corporation (2010). The positive impact of elearning. http://download.intel.com/pressroom/archive/reference/Positive_Ben efits of eLearning whitepaper.pdf

Lee, B., Yoon, J., \& Lee, I. (2009). Learners' acceptance of e-learning in South Korea: Theories and results. Journal of Computers \& Education, 53, 1320-1329. http://dx.doi.org/10.1016/j.compedu.2009.06.014

Lee, J., \& Lee, W. (2008). The relationship of e-learner's self-regulatory efficacy and perception of e-Learning environmental quality. Journal of Computers in Human Behavior, 24, 32-47. http://dx.doi.org/10.1016/j.chb.2006.12.001

Lee, L., \& Kao, C. (2010). The effect of learning motivation, total quality teaching and peer-assisted learning on study achiment: Empirical analysis from Vocaland University or Colleges' student in Taiwan. The Journal of Human Resource Adault learning, 6.

Lou, Y., Bernard, R., \& Abrami, P. (2006). Media and pedagogy in undergraduate distance education: A theory-based meta-analysis of empirical literature. Educational Technology Research and Development, 54, 141-176. http://dx.doi.org/10.1007/s11423-006-8252-x

Miller, M. (2005). Usability in e-learning. http://www.neiu.edu/ sdundis/textresources/Usability/Usability\%20i $\mathrm{n} \% 20$ E-Learning.pdf

Moore, M. (1989). Three types of interaction. The American Journal of Distance Education, 3, 1-6. http://dx.doi.org/10.1080/08923648909526659

Moore, M., \& Thompson, M. (1990). The effects of distance learning: A summary of literature. ERIC Document Reproduction Service No. 
ED330 321

Murray, M., Perez, J., Geist, D., \& Hedrich, A. (2012). Student interaction with online course content: Build it and they might come. Journal of Information Education: Research, 11.

Neo, K. (2003). Using multimedia in a constructivist learning environment in the Malaysian classroom. Australian Journal of Educational Technology, 19, 293-310.

Neo, M., \& Neo, T. (2009). Engaging students in multimedia-mediated constructivist learning-Students' perceptions. Educational Technology \& Society, 12, 254-266.

O’Malley, J., \& McCraw, H. (1999). Students' perceptions of distance learning, online learning and the traditional classroom. Online Journal of Distance Learning Administration, 2.

Paechter, M., Maier, B., \& Macher, D. (2010). Students' expectations of, and experiences in e-learning: Their relation to learning achievements and course satisfaction. Journal of Computer \& Education, 54, 222-229. http://dx.doi.org/10.1016/j.compedu.2009.08.005

Pask, G. (1995). Conversation, cognition, and learning. New York: Elsevier.

Price, L. (2004). Individual differences in learning: Cognitive control, cognitive style, and learning style. Educational Psychology, 24, 681698. http://dx.doi.org/10.1080/0144341042000262971

Roi, K. (2006). The impact of learning styles on interactivity in asynchronous e-learning. Performance Improvement, 45, 21-26. http://dx.doi.org/10.1002/pfi.4930451026

Rovai, A. (2002). Building sense of community at a distance. The International Review of Research in Open and Distance Learning, 3.

Rovai, A. P., \& Barnum, K. (2003). On-line course effectiveness: An analysis of student interactions and perceptions of learning. Journal of Distance Education, 18, 57-73.

Selim, H. (2007). Critical success factors for e-learning acceptance: Confirmatory factor models. Computer and Education, 49, 396-413. http://dx.doi.org/10.1016/j.compedu.2005.09.004

Sher, A. (2009). Assessing the relationship of student-instructor and student-student interaction to student learning and satisfaction in web-based online learning environment. Journal of Interactive Online Learning, 8, 102-120.

Singh, G., O'Donoghue, J., \& Worton, H. (2005). A study into the effects of e-learning on higher education. Journal of University Teaching and Learning Practice, 2, 13-24.

Singh, H. (2003). Building effective blended learning programs. Educational Technology, 43, 51-54.

Siritongthaworn, S., \& Krairit, D. (2006). Satisfaction in e-learning:
The context of supplementary instruction. Campus-Wide Information Systems Journal, 23, 76-91. http://dx.doi.org/10.1108/10650740610654465

Smith, R. (2010). Motivational factors in e-learning. http:/www.ruthcsmith.com/wordpress/wp-content/uploads/2012/10/ Motivation.pdf

Stash, N., Cristea, A., \& De Bra, P. (2010). Adaptation to learning styles in e-learning: Approach evaluation. http://eprints.dcs.warwick.ac.uk/157/1/10.1.1.107.8619.pdf

Sun, P., Tasi, R., Finger, G., Chen, Y., \& Yen, D. (2008). What drives a successful e-learning? An empirical investigation of critical factors influencing learner satisfaction. Computer and Education, 50, 11831202. http://dx.doi.org/10.1016/j.compedu.2006.11.007

Teare, R. (2000). Modeling the virtual university. Journal of Workplace Learning, 12, 111-123. http://dx.doi.org/10.1108/13665620010317667

Thompson, A., \& Strickland, A. (2001). Crafting and executing strategy: Text and readings. New York: McGraw-Hill.

Volery, T., \& Lord, D. (2002). Critical success factors in online education. The International Journal of Educational Management, 14, 216-223. http://dx.doi.org/10.1108/09513540010344731

Wagner, E. (1994). In support of a functional definition of interaction. The American Journal of Distance Education, 8, 6-29. http://dx.doi.org/10.1080/08923649409526852

Wagner, N., Hassanein, K., \& Head, M. (2008). Who is responsible for e-learning success in higher education? A stakeholders' analysis. Educational Technology \& Society, 11, 26-36.

Wanstreet, C. (2006). Interaction in online learning environments. Quarterly Review of Distance Education, 7, 399-411.

Young, J. (2002). Online teaching redefines faculty members' schedules, duties, and relationships with students. Washington DC: Chronicle of Higher Education.

Young, M. (2005). The motivational effects of the classroom environment in facilitating self-regulated learning. Journal of Marketing Education, 27, 25-40. http://dx.doi.org/10.1177/0273475304273346

Zhao, Y., Lei, J., Yan, B., Lai, C., \& Tan, S. (2005). What makes the difference? A practical analysis of research on the effectiveness of distance education. The Teachers College Record, 107, 1836-1884. http://dx.doi.org/10.1111/j.1467-9620.2005.00544.x

Zurita, G., Baloian, N., Baytelman, F., \& Farias, A. (2007). Developing motivating collaborative learning through participatory simulations. In G. Goos, J. hartmanis, \& J. V. Leeuwen (Eds.), Lecture notes in computer science (p. 807). Heidelberg : Springer. 